\title{
Bursa Yeşil Cami ve Türbesi'nin 1855 Depremi Sonrası Çizilmiş Planı ve Leon Parvillée Tarafından Gerçekleştirilen Onarımlar
}

\author{
The Plans of Bursa Green Mosque and its Tomb, Drawn Following the 1855 \\ Bursa Earthquake, and the Restoration Work Carried out by Leon Parvillée
}

\begin{abstract}
Ayşe BUDAK*
Öz: Osmanlılara başkentlik yapmış şehirlerden Bursa, bu unvanı sayesinde pek çok Osmanlı yapısını bünyesine katmıştır. Çelebi Mehmed tarafından inşa ettirilmiş külliye içinde bulunan ve çinilerinin rengine atfen Yeşil Cami ve Yeşil Türbe olarak adlandırılan yapılar en çok bilinenlerdendir. Taş, çini, alçı, metal ve ahşap işlemeciliğinin zengin örneklerini bünyesinde barındıran bu yapılar inşa edildikleri tarihten günümüze kadar çeşitli onarımlara tabi tutulmuştur. 1855 yılında Bursa merkezli olarak meydana gelen büyük depremde bu yapılarda hasar almıştır. 1855 depremi sonrası onarımların 1863 yılına kadar yoğun olmadığı ve asıl onarımların 1863 yılında Ahmed Vefik Paşa'nın Bursa'ya tayin edilmesi ile başladığı tarihi kaynaklardan öğrenilir. Bu onarımları ilginç kılan noktalardan biri Fransız sanatçı Leon Parvillée'nin bu onarım için Bursa'ya gelmesidir. Sanatçının adı sadece Yeşil Cami ve Türbesi'nin onarımı için geçmez. Bursa'da pek çok yapıda Ahmed Vefik Paşa ile birlikte çalışmalarına karşılık bu onarımların içeriği tam olarak bilinememektedir. Başbakanlık Osmanlı Arşivi’nde, bir deprem sonrası hazırlandığı açıklaması yer alan tarihsiz bir plan bulunur. Adı geçen plan Yeşil Cami ve Türbesi için ortak hazırlanmış olup yapıların mevcut planlarından farklılıklar göstermektedir. Bu çalışmada; Başbakanlık Osmanlı Arşivi'nde bulunan bu planın, tarihi belge ve bilgilerle hem 1855 depremi sonrası hazırlanmış olduğu ortaya konulmakta hem de bu plan üzerinden Leon Parvillée'nin gerçekleştirdiği ve en azından plan üzerinden okunabilecek tamiratlar belgelenmektedir.
\end{abstract}

Anahtar sözcükler: Bursa, Mimari, Onarım, 1855, Deprem, Leon Parvillée

Abstract: Bursa had many Ottoman structures as it had been one of the capital cities of the Ottoman State. The buildings, known as the Green Mosque and Green Tomb due to the colour of their tiles, in the complex built for Çelebi Mehmed are the best-known examples. These buildings, which include rich examples of stonework, tilework, plasterwork, metalwork and woodwork, since their construction have been subject to various repairs. They were damaged in the great earthquake in Bursa in 1855. From historical sources it is known that after the 1855 earthquake repairs did not become intensive until 1863 with the main repair works begining with the appointment to Bursa of Ahmed Vefik Pasha in 1863. One of the interesting points of these restorations is that French artist Leon Parvillée came to Bursa for these repair works. The artist not only participated in the repairs made to the Green Mosque and Tomb and although together with Ahmed Vefik Pasha, Leon Parvillée undertook much work in Bursa the nature of the repairs made are not fully known today. In the Ottoman Archives of the Prime Ministry, there is a dateless plan with a note stating it was prepared after an earthquake. This article concerns the plan was made of both the Green Mosque and Tomb and that it records differences from the existing plans of these buildings.

Keywords: Bursa, Architecture, Restoration, 1855, Earthquake, Leon Parvillée

\footnotetext{
* Dr. Öğr. Üyesi, Nevşehir Hacı Bektaş Veli Üniversitesi, Fen-Edebiyat Fakültesi, Sanat Tarihi Bölümü, Nevşehir. aysebudak@nevsehir.edu.tr
} 


\section{Giriş}

Osmanlı İmparatorluğu'nun ilk başkenti olan Bursa, dini, sosyal işlevli ve ticari birçok yapı ile ihya edilmiştir. Bu yapıların bir kısmı günümüze ulaşamamışken, bir kısmı onarımlarla günümüze ulaşmıştır. İnsan eliyle olduğu kadar doğal felaketlerle de zarar görmüş yapılar onarılarak varlıklarını korumuş, bu onarımlar kimi zaman yapıların bütünlüğünde değişikliklere neden olmuştur. İmparatorluğun ikinci kurucusu kabul edilen Çelebi Sultan Mehmed'in inşa ettirdiği ve Yeşil Cami olarak anılan zaviye ile kendisine ait türbe, ilk Osmanlı başkentinin ilk yapılarındandır ve çeşitli kereler onarım geçirerek günümüze ulaşmıştır. Bursa'nın deprem tarihine bakıldığında Osmanlı devrinde en şiddetli depremin 1855 yılında meydana geldiği görülür. 2 Mart'ta Bursa/Kemalpaşa ve 12 Nisan'da Bursa merkezli olarak meydana gelen (Özcan 1999, 75-76) depremlerin oldukça yıkıcı sonuçları olduğu bilinmektedir. 1855 yılında Bursa'da meydana gelen depremin, dini ve ticari yapıların yanı sıra konut mimarisi açısından da oldukça yıkıcı sonuçlar doğurduğu Başbakanlık Osmanlı Arşivi'nde bulunan belgelerden anlaşılmaktadır (BOA. A.MKT.NZD. 144/56, BOA. EV.D. 15785, BOA. A.AMD. 54/79, BOA. A.MKT.MHM. 233/52, BOA. A.MKT.MVL. 71/70, BOA. A.MKT.MVL.75/59, BOA. A.MKT.MVL.76/73, BOA A.MKT.MHM. 363/22). Birçok yapının hasar gördüğü deprem sonrası tutulan raporlarla netlik kazanır (Oğuzoğlu 2001, 81-88). Yeşil Türbe ve Cami' de depremden zarar gören yapılar arasındadır. 1855 tarihli defterde aşağıdaki bilgiler yer almaktadır:

"Çelebi Sultan Mehmed Han Hazretlerinin Cami-i Şeriflerinde bir
sakatlık olmayub fakat kapusu üzerinde vaki kubbenin kenar tabir
olunan mahalli harab olduğu ve eda-yı salavat olunmakta bulunduğu
minaresi şerifesine kadar münhedim ve temeline kadar münşakk olub
hedm olduğu halde muzırret ideceği ve cami-i şerif havlisinde şadırvan
ve havli divarlart külliyen münhedim olduğu ve türbe-i şerifelerinde bir
şey olmayub fakat havlisinde olan divarlarının münhedim olduğu ve
imaretin bazı mahalleri cüzice zedelenmiş olduğu medresesinde bir şey
olmadığı" (BOA. EV.D. 15785).

1855 depremi sonrası hasar gören yapıların, 1863-1867 yılları arasında dönemin Bursa yöneticisi Ahmed Vefik Paşa tarafından onartıldığ bilinmektedir. Paşa'nın onarttığı yapılardan birisi de Yeşil Camidir (Tansel 1964, 132). Onarılan diğer yapılar arasında Ulu Cami, Orhan Zaviyesi ve Muradiye Camisi, Emir Sultan Külliyesi ve Muradiye Külliyesi avlusunda bulunan türbeler de vardır. Yapıların onarımı için Ahmed Vefik Paşa'nın kente davet ettiği isim Fransız Leon Parvillée'dir. Bu mimarın kentteki geniş çaplı onarımlarda rol aldığı bilinmesine karşılık, yapılara yaptığı müdahalelerin tümü kesin olarak bilinmez.

Başbakanlık Osmanlı Arşivi'nde Bursa Yeşil Cami ve Türbesinin tarihsiz planları mevcuttur (BOA. PLK. 03443). İncelenen bu planın, cami ve türbenin mevcut planlarından farklılıklar gösterdiği tespit edilmiştir. Tarihsiz olmasına karş1lık planda "hareket-i arzda harap olan" ifadesi bulunmaktadır. Bu ifadeden, planın deprem sonrası hazırlanmış mevcut durumları gösteren plan olduğu anlaşılmaktadır. Arşivde bulunan bu tarihsiz planın hazırlanış şekli (renklendirme yöntemi gibi) geç dönem olabileceğini düşündürtmektedir. Bu nedenle bahsi geçen planın 1855 depremi sonrası yapıların mevcut durumunu gösteren plan olma ihtimali oldukça kuvvetlidir. Bu makalede, 1855 depremi sonrası hazırlandığ $\breve{t a h m i n}$ edilen bu plan temel alınarak, bahsi geçen deprem sonrası Bursa'da Yeşil Cami, Yeşil Türbe, Orhan Camisi, Muradiye Camisi ve Ulu Cami’yi onardığını söyleyen Leon Parvillée'nin (Aoki 2002, 9), Yeşil Cami ve Türbe'sinde yapmış olabileceği onarım dokunuşlarına dair bazı tespitler değerlendirilmiştir. Yeşil Caminin Parvillée tarafından çizilmiş planıyla, 1873 tarihli Usul-i Mimar-i Osmani kitabında yer alan planları, 
arşivde bulunan planla kıyaslanarak değerlendirme ve çıkarımlar yapılmıştır. Yukarıda bahsi geçen planların analizine geçmeden önce Leon Parvillée ve onu Bursa'ya davet eden Ahmed Vefik Paşa'nın yollarının nasıl kesiştiğine bakılabilir.

\section{Ahmed Vefik Paşa ve Leon Parvillée}

Tanzimat dönemi ile birlikte önemli dönüşüm yaşayan ve kent kimliğine yeni unsurlar eklenen Osmanlı şehirlerinden birisi hiç şüphesiz Bursa'dır. 1855 yılında meydana gelen depremde büyük hasar gördüğü bilinen kentin geniş çaplı onarımı, Tanzimat dönemi mimarlık anlayışının yansıtılması için de zemin hazırlamıştır. Osmanlı yönetimi, depremde büyük hasar gördüğü bilinen Bursa'da 1860-1882 arasında, Tanzimat'ın modernlik ve Osmanlilık idealine uygun bir yeniden inşa çerçevesinde, Bursa'ya eski görünümünü kazandıracak bir restorasyona girişmiştir (Saint Laurent 1996, 83-86). 19. yüzyılın en önemli entelektüellerinden olan, tercümanlık, sefirlik, oyun yazarlığ devlet kademesinin birçok alanında çalışmış ve göreve getirilmiş Ahmed Vefik Paşa, Tanzimat döneminin de önemli ve renkli aktörlerindendir ve bu girişimin en önemli ismidir. Tercümanlıkla başladığı çalışma yaşamında 1860 yılında Paris'e büyük elçi olarak atanır ve bir yıl süre ile bu görevi yerine getirir (Akün 1989, 145). Ahmed Vefik Paşa, kent çehresine önemli katkılar sağladığ1 Bursa'da iki kez görevli bulunmuştur. Paşa'nın Bursa'da yerleşik olarak ilk çalışması 1863-64'de Anadolu Sağ Kolu Ciheti Müfettişi iken olmuştur (Akün 1989, 146). 1864 yılında bu görevden azledilmesinin ardından Bursa'dan ayrılan ve devlet kademesinde çeşitli görevleri yerine getiren Ahmed Vefik Paşa'nın, Bursa'ya yeniden gelmesi 1879 yılında bu şehre vali olarak atanması ile olmuştur. Bu görevi 1882 yılına kadar sürdürmüş ve bu tarihte yeniden görevinden azledilmiştir (Akün 1989, 148). Ahmed Vefik Paşa'nın 1855 depremi ile büyük yıkıma uğramış Bursa'da 1863 yılında başlattığı geniş çaplı restorasyonlara ve yeni bir kent oluşturmak için başlattığı çalışmalara 1879 yılında yeniden Bursa'ya tayin edilmesi ile devam ettiği bilinmektedir. 1864'de Bursa'dan ayrılması ile yeni yollar ve yeni kamu kurumu inşaları dışında onarımların da sekteye uğradığını arşiv belgelerindeki bilgiler göstermektedir. 1866/ 1867 tarihli belgeden tamirlerinin tam anlamıyla bitirilip yapıların hizmete açılamadığı anlaşılıyor. Belge, Rus sefirinin Bursa'ya gelişinde yapıları bu halde görmesinin ayrıca bir üzüntü nedeni olduğu ifadeleri ile devam etmektedir:

"Sultan Orhan ve Hüdavendigar Gazi Murad-ı evvel ve Yıldırım Bayezid
ve Çelebi Mehmed Sultan hazeratının cevami-i şerife ve türbe-i münife-
lerinin vukubulan hareket-i arz tesirattyla bazı mahelleri külliyen
münhedim olmuş ve bazlları dahi zedelenmiş olmaslyla bunların ekser
mahalleri saye-i ...hazret-i şehriyare inşa ve tamir kılınmış ise de henüz
reside-i derece-i ikmal olmamıs ve bu hal ile teşrifleri icra olunarak
kapalu kalmış olduğu Bursa'ya muvasalat kemteranemde nazar-l
teessüfle görülmüşs olduğu" (BOA. MKT. MHM. 386/87).

Siyasi kimliği sayesinde eski eserlerin tamiri ile de ilgilenmiş olan Ahmed Vefik Paşa'nın Evkaf Nazırıyken Süleymaniye Camisi'ni onarttığı bilinmektedir (Tansel 1964, 129). 15 Şubat 1862'de bu caminin yeniden ibadete açılması ve caminin onarımında oynadığ 1 rol nedeniyle kendisine ikinci rütbeden Osmanî Nişanı verilmiştir (Akün 1989, 146). Tanzimat Dönemi’nde Osmanlı modernleşmesinin bir parçası olarak, 1830'da II. Mahmud görünmez/ulaşılmaz padişah algısını değiştirecek bir tutumla memleket gezilerine çıkmıştır (Kırlı 2008, 27-37). Oğulları Abdülmecid ve Abdülaziz'de bu yeniliği benimsemiş ve yurt gezilerine çıkmış (Kırlı 2008, 30), bu geziler kapsamında Abdülmecid 1844'de Abdülaziz ise 1861'de Bursa'ya gelmişler her iki padişahın ziyaretinde kalmaları için birer köşk inşa edilmiştir (Saint Laurent 1996, 90). Abdülaziz'in ziyareti tarih açısından Ahmed Vefik Paşa'nın 1863'de Bursa'da görevlendirilmesinin hemen 
öncesidir. Sultan Abdülaziz'in deprem sonrası kentin imara ve yenilenmeye duyduğu ihtiyacı gördüğü düşünülürse, Bursa'ya tayin edilen ve hemen öncesinde Süleymaniye Camisi'ni onartarak bir nişanla taltif edilen Ahmed Vefik Paşa'dan, Bursa yapılarının onarımına dair talep de bulunup bulunmadığ 1 tahmin edilememektedir. Ancak, bu ikilinin Bursa'nın tamirine dair bir konuşma yapmış olabileceği tasavvur edilebilir.

Bursa yapılarının tamirinde görevlendirilen Fransız mimar Leon Parvillée, 1830-1885 yılları arasında yaşamış ve aslında Paris'te heykeltıraş olarak eğitim almıştır (Aoki Girardelli 2013, 67). Parvillée'nin İstanbul'a ilk gelişi 1851 yılında olmuş ve iki yıl boyunca İstanbul'da kalmıştır (Saint Laurent 1986, 248-249). 1855 yılında iki yıllık bir aradan sonra, Abdülaziz'in sarayında çalışmak üzere tekrar İstanbul'a gelmiştir (Saint Laurent 1986, 249). 19. yüzyılın yabancı kaynaklarında Parvillée "Şehzade Abdülaziz'in inşaatlarının müteahhidi ve müteşebbisi" olarak tanıtılmaktadır (Gabriel 2010, 81). Mimarın Fransa'ya ne zaman döndüğü kesin olarak bilinememekle birlikte 1866 yılında Fransa'da atölyesi bulunduğu için bu tarihlerde döndüğü tahmin edilmektedir (Aoki 2002, 137). 1850'lerde, Osmanlı topraklarına seyahat eden mimarlarla ve Osmanlı'nın Fransa'ya gönderdiği öğrencilerle, Fransız ve Osmanlı mimarisi arasında bir etkileşim olmuştur (Saint Laurent 1986, 258). Leon Parvillée'nin 1863'de Bursa'ya gittiğinde, mevcut Fransız mimari ve restorasyon teorileriyle, İstanbul'daki araştırmalarının meyvesi olarak Osmanlı mimarisiyle ilgili bilgisini artırdığı düşünülmektedir (Saint Laurent 1986, 258-259). Ahmed Vefik Paşa, 1860'da Osmanlı'nın Paris büyükelçisi olarak çalıştığında tarihi anıtların restorasyon ve mimarlık teorilerine dair Fransız görüşlerini biliyor olmalı ve Parvillée'yi Bursa' ya davet ederken, onun bir mimar olarak kalitesine ve klasik Osmanlı mimari bilgisine de vakıf olmalıdır (Saint Laurent 1986, 259). 1860 yılında Ahmed Vefik Paşa'nın Paris Büyükelçiliği sırasında o tarihlerde İstanbul'da yaşayan Parvillée, Fransız dostları tarafından Paşa'ya tavsiye edilmiş olabileceği gibi, Ahmed Vefik Paşa'nın 1862 yılında Süleymaniye Camisi'nin onarımıyla ilgilenirken İstanbul'da bu iki ismin tanışmış olması da ihtimal dâhilindedir. Parvillée'nin kendiside dahil olmak üzere mimarın Bursa'da yaptığı onarımların ayrıntılarını veren bir kaynak bulunmaz. Bilinenlerse; Yeşil Cami ve Türbesi'nin çinilerinin sıva altından çıkarılması ve onarılması, caminin kubbesinin onarılması ve türbe vitraylarının onarımıdır. 1863 tarihli bir belge Bursa Yeşil Cami ile ilgili yapılan keşifle ilgili olup bu belgeden Parvilée'nin 3000 kuruş maaşla teftiş heyetinde görev aldığı öğrenilmektedir (Yavaş 2009, 593). Yeşil Cami ve türbesinin onarımlarının 200.000 kuruşa mal olacağı yine aynı belgeden tespit edilebilmektedir. Ancak tamir olunacak yerlerden bahsedilmemektedir (Yavaş 2009, 593).

Parvillée'nin restorasyon sırasında özellikle türbeden bazı çini panoları beraberinde götürdüğü bilinmektedir ve bu çini panolar şimdilerde Victoria and Albert Müzesi'ndedir (Eroğlu, Başaran 2016, 331-352). Başbakanlık Osmanlı Arşivi'nde bulunan Yeşil Cami ve Türbesinin planları üzerinden, Parvillée'nin en azından bu yapıların planları üzerinden okunabilecek onarımlara dair çıkarımlar aşağıda tartışılmaktadır.

\section{Yeşil Cami ve Türbesi}

Çelebi Mehmed tarafından Bursa'da inşa ettirilmiş zaviye, imaret, medrese ve türbeden oluşan külliye (Kuban 2007, 96), 1413-1421 yılları arasında inşa ettirilmiş ancak süslemelerin yapımı 1424 yılına kadar sürmüştür (Kuban 2007, 96-102). Külliyenin mimarı Hacı İvaz Paşa, süslemelerini yapan sanatçı ise Nakkaş Ali bin İlyas Ali’dir (Kuban 2007, 96-102). Çelebi Mehmed tarafından inşa ettirilen külliyenin camisi, zaviyeli cami, ters t planlı cami olarak da adlandırılan planda inşa edilmiştir (Fig. 1). Çeşitli kereler onarım geçirerek günümüze ulaşmış yapının geçirdiği değişikliklere dair çıkarım yapılabilmesini sağlayacak en önemli belgelerden olan ve daha önce herhangi bir çalışmaya konu olmamış plan, Başbakanlık Osmanlı Arşivi'nde bulunmaktadır ve bu çalışmanın temelini oluşturmaktadır (Fig. 2). Tarihsiz plan, caminin giriş katına ait 
olup, Yeşil Cami ve Türbesi için ortak düzenlenmiştir. Avlu duvarlarının yanı sıra türbe çevresinin mevcut halinin detaylandırılmasıyla, aslında bu plan vaziyet planı görüntüsü vermektedir. Cami planının yanına eklenmiş açıklama metni şu şekildedir: "Bursa'da vaki cennet mekan Gazi Çelebi Sultan Mehmed Han tabe serah hazretlerinin hareket-i arzdan harab ve münşak olmuş olan kargir cami-i şerif ve türbe-i aliyelerinin tersim olunan resmi musattahidir". Bir deprem sonrası hazırlanan bu planın, cami ve türbenin mevcut planlarından farklılıklar gösterdiği anlaşılmaktadır. Yapıların çevresinde de farklılıklar olduğu tespit edilebilmektedir. Cami planı ile başlanılıp bu farklılıklar maddeler halinde sıralandığında:

Günümüzde mevcut olan ancak arşivdeki planda görülmeyen detaylar şunlardır:

1- Doğuda bulunan minare

2- Caminin içinde girişte yer alan devşirme dört adet sütun.

3- Bu sütunların bulunduğu yerde oluşturulan koridor.

4- Alt kat mahfillerinden koridora açılan pencereler.

5- Girişin iki yanında bulunan odaların kapıları.

6- Kuzeybatı tabhane hücresinin batı eyvana açılan kapısı.

7- Caminin ortasında bulunan şadırvan.

8- Güneybatı ve güneydoğu tabhane hücrelerinin güney duvarında bulunan nişler.

Günümüzde mevcut olmayan ancak arşivdeki planda görülen ayrıntılar ise şu şekildedir:

1- Caminin dışında giriş kapısının doğusunda bulunan merdiven ve merdivenle çıkılan alan.

2- Yine caminin dışında doğu cephede bulunan merdiven.

3- Caminin içinde güneybatı cephedeki hücre girişinin hemen önünde bulunan merdivenli sahın.

Camideki bu değişimlerin hangi tarih aralığında meydana geldiğini anlayabilmek için, mevcut olan ve olmayan detaylara daha yakından bakılabilir. İlk olarak yapının ne zaman çifte minareli olduğu yapıya ikinci minarenin ne zaman eklendiği tartışılabilir. Minarelerin giriş biçimini anormal bulan Albert Gabriel, ikinci minarenin 19. yüzyll sonunda inşa edildiğini kabul eder (Gabriel 2010, 84). Minarelerin 19. yüzyılın sonlarında yıkıldığı ve her ikisinin de Reşid Mümtaz Paşa'nın valiliği döneminde (1903-1906) yeniden inşa edildiği bilgisi bulunmaktadır (Pay 2010, 55). Bursa Müzesi Kütüphanesi'nde 431 numarada kayıtlı olan Hüdavendigar Vilayeti İmar Defteri, Mefail Hızlı tarafından yayınlanmıştır. 1891-1893 yılları arasında Bursa Vilayeti'nde gerçekleştirilen imar faaliyetlerine yer verilen defterde, caminin çifte minaresi ve kubbe kurşunları ile tamir edildiği ifadesi bulunur (Hızlı 1993, 237).1875 yılında iki minarenin sandıklarına 224 kuruş harcandığı bilgisine ulaşılır (Pay 2010, 55). 1873 Viyana Sergisi için, sergi komisyonu başkanı Edhem Paşa'nın girişimleriyle sergi kitabı Usul-i Mimar-i Osmani hazırlanmıştır. Adı geçen kitabın içinde yer alan ve Osmanlı mimarisini tanıtmak üzere seçilmiş örneklerden birisi de Yeşil Cami'dir. Usul-i Mimar-i Osmani kitabının metin kısmından minare merdivenlerinin son cemaat yerinin sağında ve solunda olduğu, yukarı mahfilede bu merdivenlerden çıkıldığ bilgisine ulaşılarak (yapı, ön cephe çiziminde her ne kadar tek minareli olarak çizilmiş olsada) bu tarihte yapının çifte minareli olduğu bilgisi kesinleşir (Edhem Paşa 2010, 17) Yapının tek minareli olduğunu gösteren en eski belgelerden birisi 1623 y1lına aittir. 1623 tarihli sicilden minarenin kurşun, tahta ve direklerinin çürüyüp, şerefesinin tamire muhtaç olduğu Ayverdi tarafindan aktarılır (Ayverdi 1989, 51) yani bu yüzyılda yapı tek minarelidir.

1623-1873 yılları aralığında inşa edilmiş ikinci minarenin 1855 depremi sonrası Leon Parvilée onarımı sırasında eklenip eklenmediği noktasına yoğunlaşıldığında, ilk olarak Evliya Çelebi'nin anlatımına bakılabilir. 17. yüzyıl seyyahı Evliya Çelebi'de yapının tek tabakalı minaresi olduğunu ve yeşil çinilerle süslü olduğunu bu nedenle, yapının Yeşil Cami olarak 
adlandırıldığını bilgisine ulaşılır (Kurşun \& Kahraman 2011, 13). 1825 tarihli belgeler minare külahının tamirinden bahseder (Ayverdi 1989, 54) yani 1825'de cami hala tek minarelidir. 1833-1837 yılları arasında ve 1843 yılında iki kez Türkiye'ye gelen seyyah Charles Texier'de yapıyı tek minareli olarak anlatır (Texier 2002, 225). 1855 depremi sonrası hazırlanan rapor Yusuf Oğuzoğlu tarafından yayınlanmıştır. Raporda "minaresi şerefesine kadar yıkılmıştır, minarenin alt tarafı ise çatlamıştır" (Oğuzoğlu 2001, 82) ifadesi bulunur. Bu raporun bize sunduğu en önemli bilgi, 1855 yılında Yeşil Cami'nin tek minareli bir yapı olduğunu ortaya koymasıdır. Yap1, Parvillée tarafından yapılan cephe çiziminde tek minareli olarak gösterilir (Fig. 3).

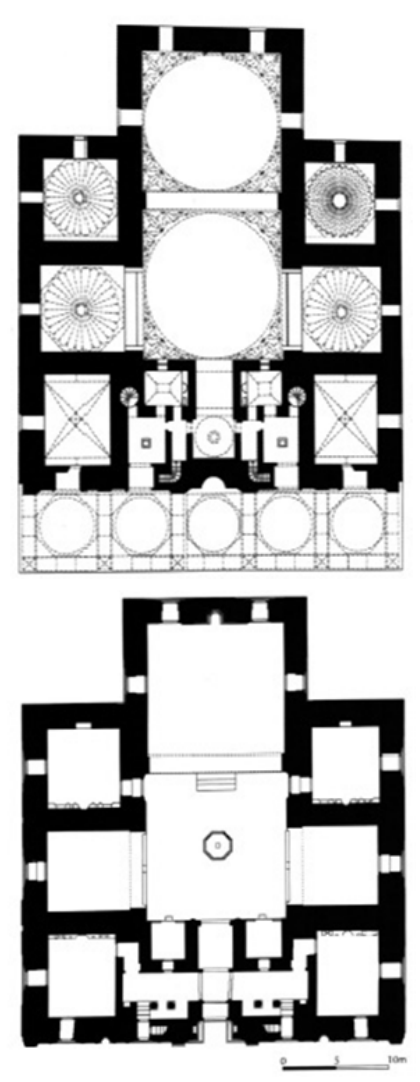

Fig. 1. Yeşil Caminin Üst ve Giriş Kat Planları (D. Kuban'dan)

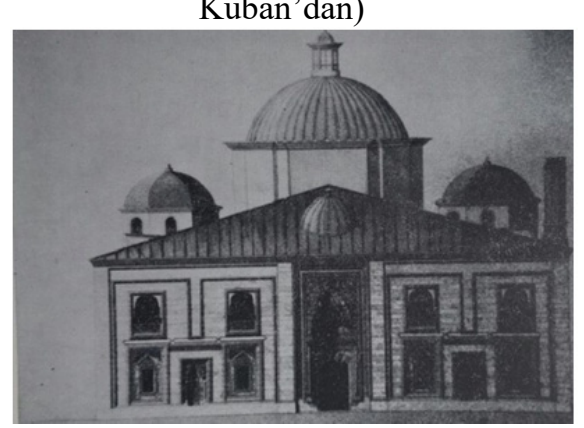

Fig. 3. Leon Parvillée Tarafından Çizilmiş Yeşil Caminin Cephe Çizimi ve Planı (B. Saint Laurent'ten)
Fig. 2. Başbakanlık Osmanlı Arşivi'nde Bulunan Tarihsiz Plan

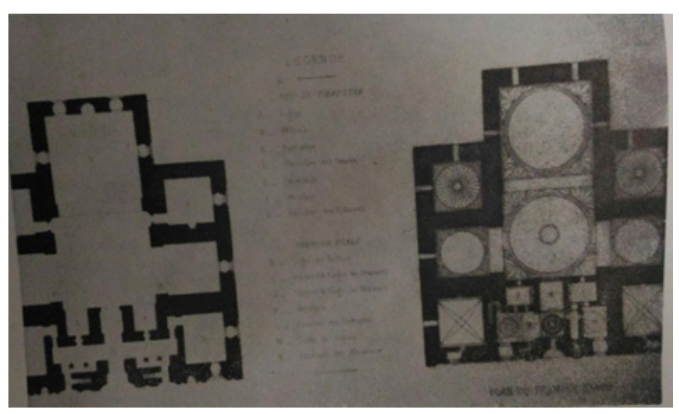




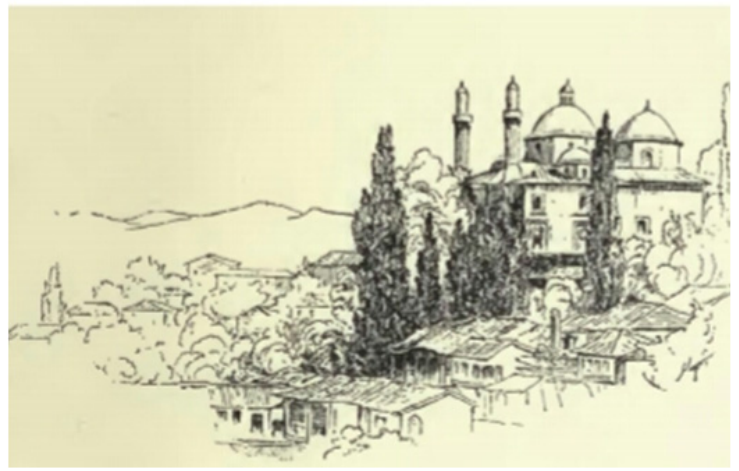

Fig. 4. Edwin A. Grosnevor'da Yeşil Camisi (1866)

(Fahri Y1ldırım'dan)

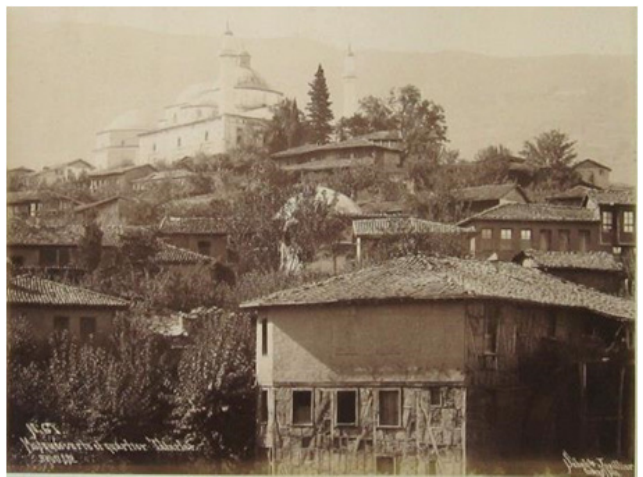

Fig. 5. 1880’lerde Yeşil Cami (http://www.luminouslint.com/_phv_app.php?/p/1_S ebah_Joaillier)

Aynı şekilde 1873 tarihli Usul-i Mimar-i Osmani kitabında bulunan Yeşil Caminin cephe çiziminde de yapı tek minareli olarak gösterilmiştir. Ancak aynı kitabın metin kısmında minarelere çıkılan merdiven betimlemesinden yapının çifte minareli olarak tanımlandığ 1 yukarıda ifade edilmişti. Her iki çizimde de yapının çifte minareli olmasına karşılık tek minareli gösterilmesi ve minarenin belli bir seviyeden kesilerek gösterilmesinin en azından bu yüzyıl için bir çizim tekniği olduğu düşünebilir. Her iki planda da minare belli bir seviyeden kesilerek gösterildiği için şerefe ve külah biçimine dair bir yorum getirilememektedir. 1862 yılı civarında Bursa'ya gelen seyyahlardan Moustier minarelerdeki porselen kaplamaların uzun süre önce kaybolduğunu söyler (Yıldırım 2014, 293), Moustier'in minarelerdeki kaplamalarla ilgili söylediğinden daha önemli olan minare değil minareler ifadesidir. Bu tarihte caminin artık çifte minareli olduğu onun tanıklığında kesinleşir ve bu ifade çifte minare uygulamasını 1855 depremi sonrası 1863 'de yapılan onarımlara bir adım daha yaklaştırır ve hatta kesinleştirir. Ancak tarih açısından bir yıllık bir fark bulunmaktadır. Bu da seyyahın Bursa'ya gelişinin kesin tarihinin sorgulanmasina neden olur. 1866 y1lında Bursa'ya gelen seyyahlardan Grosnevor'da bulunan resimde, cami çifte minareli olarak gösterilir (Fig. 4). Eldeki tüm bu tarihsel veriler, doğuda bulunan minarenin Leon Parvillée tarafından 1863 onarımında eklendiğini ortaya koymaktadır. 1880'li yıllara ait fotoğrafta da minarelerin Grosnevor çizimine benzediği dikkati çeker (Fig. 5) ve minarelerin formu günümüzdekinden farklıdır (Fig. 6-7). 1903-1906 yılları arasında yıkıldığ için yeniden inşa edildiği bilinen minarelerin Parvillée onarımında tasarlanan halinden farklılaştı̆̆ 1 anlaşılmaktadır.

Yeşil Cami ile ilgili temel tartışmalardan biri, caminin önünde bir son cemaat yerinin bulunup bulunmadığıdır. Kuzey cephede bulunan çıkmalar nedeniyle bir son cemaat yerinin tasarlanmış olduğu ve bundan vazgeçildiği ya da vazgeçilmek zorunda kalındığı ya da inşa edilmiş son cemaat revağının bilinmeyen bir tarihte yıkıldığı yaygın kanaatler arasındadır. Arşivde bulunan tarihsiz planda da caminin önünde bir son cemaat yerinin bulunmadığ 1 görülür. Planda şadırvanın bulunduğu kısım "avlu" olarak belirtilmiş, caminin önünde bulunan ve muhtemelen şimdi olduğu gibi zeminden yükseltilmiş
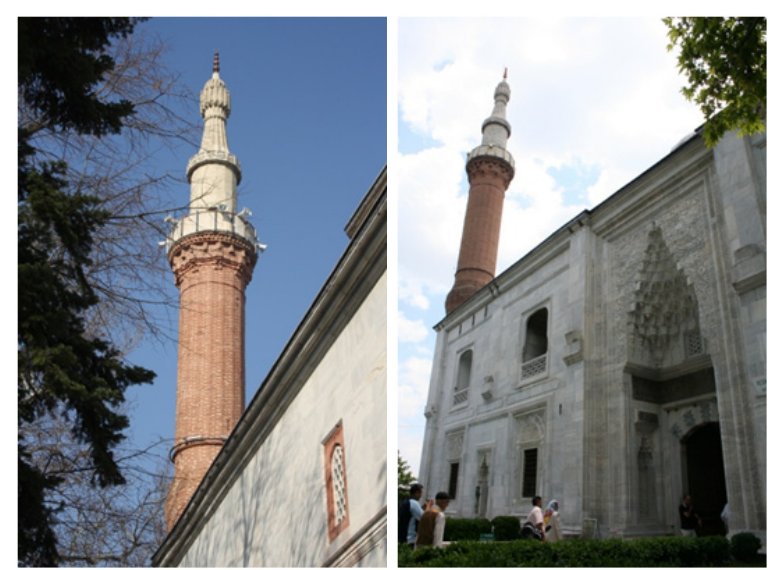

Fig. 6-7. Bursa Yeşil Cami Minareleri 
bölümlerde " $b u$ dahi" ve bu dahinin kısaltması şeklinde açıklanmış, yani avlu olarak tanımlanmıştır. Yapının içinde kullanılan devşirme sütunlar Doğu Roma Dönemi sütun başlıkları olup VI. yüzyıla tarihlenmektedir (Ermiş 2016, 104). Yapıda Doğu Roma Dönemi sütunlarına iç mekânda ve mahfile çıkışta yer verilmesi ve mahfille ilişkisi, kamusal özellikleri göz önünde bulundurularak Osmanlı'nın ve I. Mehmed'in kendini kanıtlama arzusuyla kendinden önceki güçlü imparatorluğun malzemesini kullanması bilinçli bir tercih olarak nitelenmektedir (Ermiş 2016, 100).
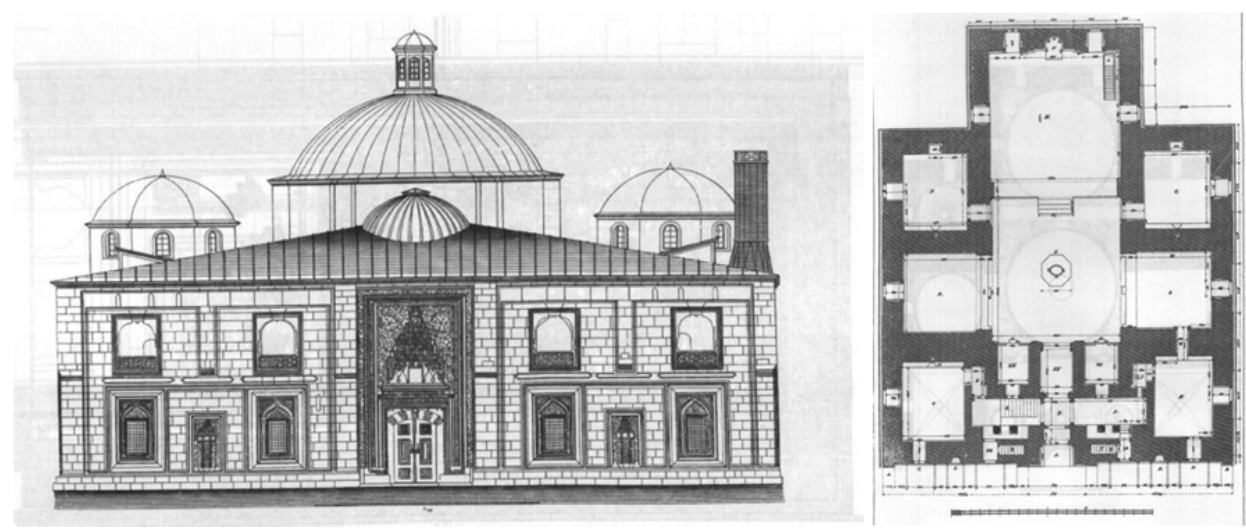

Fig. 8-9. Bursa Yeşil Cami Cephe ve Giriş Kat Planı, Usul-i Mimar-i Osmani'den

Ancak arşivde bulunan tarihsiz planda yapının içinde, girişteki dört adet sütunun bulunmadığı dikkati çeker. Parvillée'ye ait çizimde ve 1873 tarihli Usul-i Mimar-i Osmani'de ise bu dört adet sütun mevcuttur (Fig. 3, 8, 9). Usul-i Mimar-i Osmani kitabında sekiz kareden oluştuğu belirtilen cami ile ilgili en ilginç yaklaşım caminin son cemaat yeri olarak tanımlanan bölümüdür:

"kapıdan dühûl olundukda dört aded sütûn mevzu'son cemâ'at mahlline girilir. Zikr olunan sütunlar haylice müzeyyen ise de Bizantin zamanında metruk ba'zı âsâr-ı mimariyeden alınmış olunduğundan gayr-i matbû'dur. Korint usûll-i mi'mârîsi taklidi olan ebniyenin âsâr-l mütebâkiyesinden olan işbu sütunlar karanlıkça bir mahalde konulmuş olduğundan Mimar Illyas rahmetu'llâhi aleyhin eser-i bedî'i olan işbu binâ-yı dil-ârânın letafetini muhill olmamuşdır" (Edhem Paşa 2010, 17).

Yapının mimarı Hacı İvaz Paşa olmasına karşılık, yapının süsleme programının sorumlusu Nakkaş Ali Bin İlyas yapının mimarı olarak nitelenmektedir. Son cemaat yeri olarak tanımlanan bu bölüm kapıdan girdikten sonraki holdür (Fig.10-11). Doğu Roma yapı kalıntılarından getirildiği anlaşılan bu sütunların ne zaman yapıya eklendiği belirtilmez. Ancak karanlıkça bir yerde kullanıldığı için, Mimar İlyas'ın gönüllere hoşnutluk veren bu güzel eserine zararları yoktur denilmektedir. Bu ifade bile bu sütunların yapının orijinalinde bulunmayıp sonradan yapıya ilave edildiğinin başı başına kanıtı kabul edilebilir. Bu açıklama, sütunların ne zaman yapıya eklendiğine dair bir ipucu vermese bile, sütunların yapının mimarı tarafindan eklenmediğini hissettirip, orada bulunmalarını aklamaya yönelik bir açıklama olarak okunabilir. Evliya Çelebi'de yapı için "içinde asla sütun yoktur" (Kurşun,

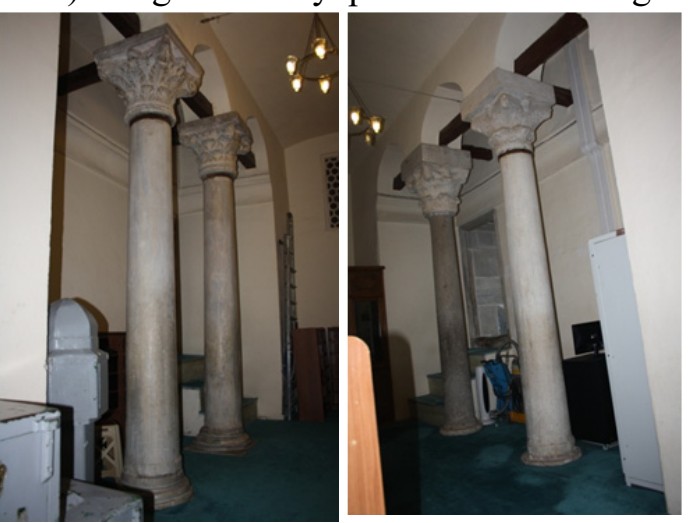

Fig. 10-11. Bursa Yeşil Caminin İçinde, Girişin Doğu ve Batısında Bulunan Sütunlar Kahraman 2013, 13) şeklinde kesin bir ifade kullanır. Yeşil Cami’nin kuzey cephesinde bulunan 
çıkmalar nedeniyle yapının bir son cemaat yerine sahip olup yıkıldığı ya da yapının banisi Çelebi Mehmed'in ölümü nedeniyle bu kısmın yarım kalmış olabileceği tartışmalarına karşıılık, yapının süslemeli ön cephesini kapatmamak için, başta tasarlanmasına karşılık bilinçli olarak son cemaat yeri inşaatından vazgeçilip revaklı girişin süslemeye feda edildiği görüşü ağır basmaktadır (Özbek 2002, 326). Bu sütunların Parvillée çiziminde görülmesi ve 1855 depremi sonrası yapılan çizimde bulunmaması nedeniyle, Doğu Roma yapılarından devşirilmişs sütunlarla yapılmış ve "son cemaat" yeri olarak adlandırılmış bu bölüm Parvillée'nin eseri olarak görülebilir. Parvillée, ön cephenin ihtişamlı süslemesini kapatma cesaretini kendinde göremeyen ve "son cemaat bölümünü" yapının içine taşıyan kişi olmalıdır. Devşirilmiş sütunların 1855'den sonra yapıya eklendiğinin ortaya çıkmasıyla cevaplanması gereken bir diğer soru 19. yüzyılın ikinci yarısında bu sütunların hangi Doğu Roma yapısından taşınmış olabileceğidir.

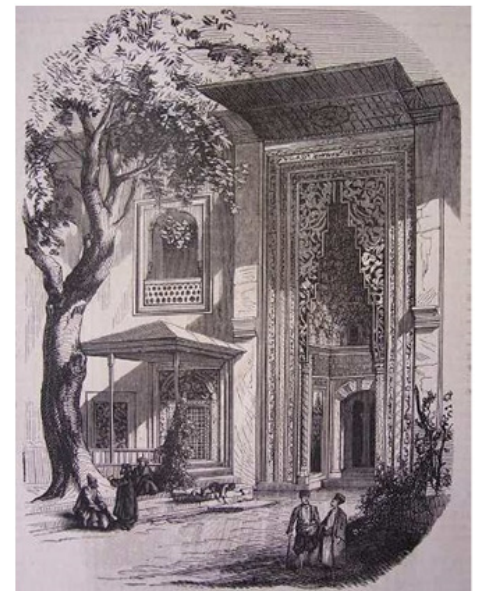

Fig. 12. Yeşil Cami Önü 1852 (M.Sevim’den)

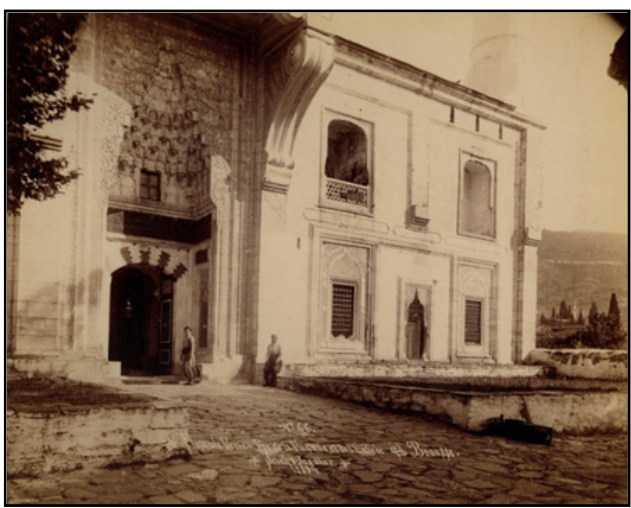

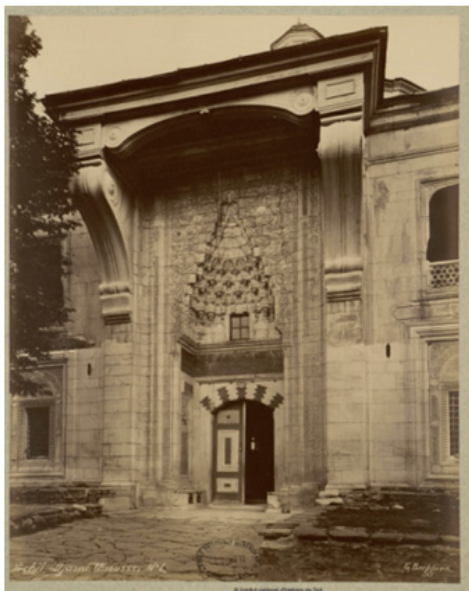

Fig. 13. Yeşil Cami Girişi 1879 tarihli fotoğraf: http://bibliotheque-numerique.inha.fr/collection/

?esq $=$ bursa\&esa $=$ resetall\&navigation $=0 \& \mathrm{x}=0 \& \mathrm{y}=0$

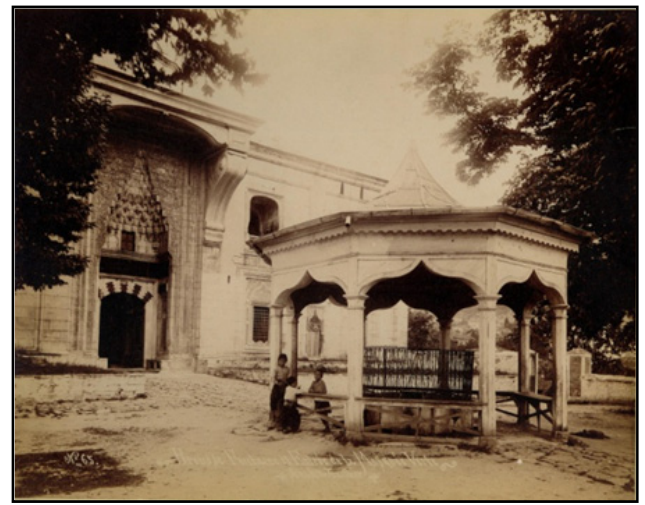

Fig. 14-15. 1880-1890’lı yıllarda Yeşil Cami Avlusundan Taç Kapı ve Kuzey Cephenin Görünümü (İstanbul Üniversitesi Nadir Eserler Kitaplığı)

1855 depremine kadar Bursa'da, kısmen ayakta kalabilmiş Doğu Roma yapılarından birisi Hagios Ioannes Manastırı'dır. Sultan Osman ve Orhan Türbeleri’nin bu manastırın bir bölümünün üzerine inşa edilmesine karşı1ık, bu manastırın yan kanatları ile birlikte 1855 depremine kadar ulaştığı bilinmektedir (Tekinalp 2010, 173). Ahmed Vefik Paşa'nın Bursa'da yaptırdığ 1 onarım çalışmaları sırasında, çevresindeki köhne evlerden görünmez olan Osman ve Orhan Gazi Türbeleri'nin, çevrelerinin açılarak ortaya çıkarıldığı bilinmektedir (Akün 1989, 146). Yeşil Cami içindeki sütunların, Osman ve Orhan Gazi Türbeleri'nin çevre düzenlemeleri sırasında bu manastırdan getirilmiş olması ihtimal dâhilindedir. 
1852 tarihli bir gravürde kapının üzerinde çatı hizasından uzanan düz bir sundurma görülür (Fig.12). 19. yüzyılın sonlarına tarihlenen fotoğraflarda da caminin taç kapısının üzerinde 1852 tarihli gravürde görülenden farklı bir sundurma dikkati çekmektedir (Fig.13,14,15). A. Gabriel 19. yüzyıl onarımlarından birinde eklenmiş bu sundurmanın, mermere benzetilmiş ahşap ve harçtan oluşan basit malzemeli ölçüsüz iki konsol tarafından taşındığını belirtir (Gabriel 2010, 81). 1880-1890'l1 yıllara ait fotoğraflarda görülen ampir üsluptaki bu sundurmanın yeni olduğu düşünülmektedir (Ayverdi 1989, 88). Bu sundurma ne Parvillée'nin yaptığ 1 cephe çiziminde nede Usul-i Mimar-i Osmani kitabındaki cephe çiziminde görülmektedir (Fig.3-8). Aynı sundurma 20. yüzyılın ilk yarısında kaldırılmıştır. Yapının içine eklenen sütunlarla bir bütünlük içinde düşünüldügün̈e, içerde bir son cemaat yeri oluşturulması sırasında yapının dışına da bu sundurmanın eklendiği düşünülebilir. Böylece minimal boyutta da olsa yapının içinde hem bir son cemaat revağ 1 elde edilmiş hem de yapının dişındaki

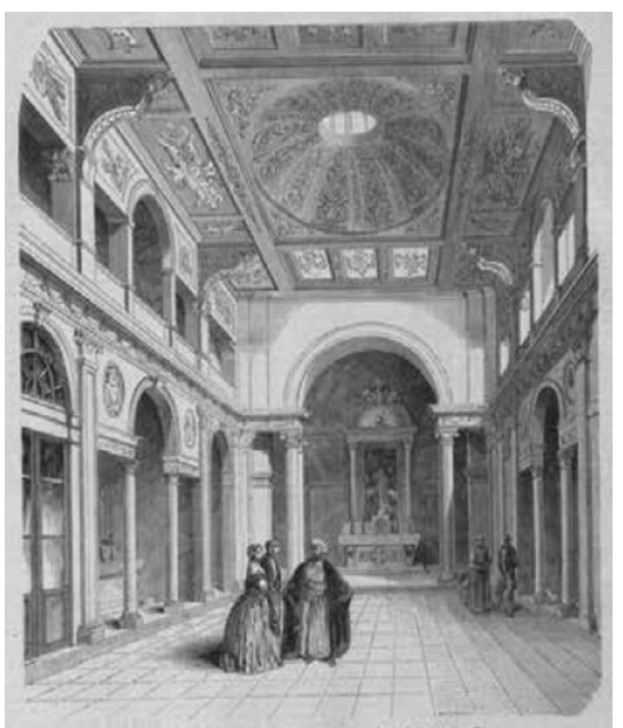

Fig. 16. Parvillée ve G. Fossatti Tarafindan Tasarlanan Pera'daki St. John Chisostom Roman Katolik Kilisesinin Açılışını Duyuran Gazete Haberindeki Görsel (1854), (M.A. Girardelli'den) tamamlanmamış görünüm geniş kapı sundurmayla bertaraf edilmiștir.

İstanbul'da Osmanlı tarihi eserleri üzerine gözlemler yapan Leon Parvillée için bir caminin belirgin dış cephe unsurları birden çok minare ve revaklar olmalıdır. Zira 19. yüzyılın ikinci yarısında payitaht İstanbul bu tarz anıtsal yapılarla doluydu. Leon Parvillée'nin G. Fossatti ile birlikte tasarladığı 1854 tarihli Pera'daki St. John Chisostom Roman Katolik Kilisesi'nde üst örtünün Yeşil Cami kapı saçağını taşıyan konsollara benzer konsollarla taşındığı görülür (Fig. 16). Bu görüntü, Yeşil Cami önündeki saçağın Parvillée tarafından eklendiğinin kesin bir kanıtı olmasa da, en azından mimarın yaklaşımını anlamamıza yardımcı olur.

Parvillée tarafından yapılan çizimde ve Usul-i Mimar-i Osmani kitabındaki cephe çizimlerinde bu sundurmaya yer verilmemesi nedeniyle bu bölümün kapıya eklenmesini Parvillée onarımına bağlarken ki çekince, 1852 tarihli gravürde görülen kapının üzerindeki düz sundurmanın da cephe çizimlerinde gösterilmemesiyle bir parça olsun dağılır. Taç kapının süslemelerini kapatmamak için (ki taç kapı süslemeleri bu çizimlerde detaylandırılmaktadır) sundurmanın çizilmediği düşünülebilir. Elimizdeki arşiv planından anlaşılan bir diğer konu yapının içinde, sütunların eklendiği bu alanda yan hücrelere geçişi de sağlayan bir koridor elde edildiğidir (Fig. 17). Arşiv'de bulunan plandan anlaşıldığı üzere kuzeydoğu ve kuzeybatı tabhane hücreleri planın çizildiği dönemde orijinalinden değişikliğe uğramış ve içerden girişleri kapatılmıştı. 1552 tarihli bir sicilde şu ifadeler vardır:

\section{“...tavhânelerin yolu dahî dışarıdan vaz' olunsa câmi'-i şerîf içerisü âyende ve revendeye memer olmayub nezâfet üzre olunub müslümanlara vus'at üzre olurdu..." (Ayverdi 1989, 50).}

Yukarıdaki ifadelerden tabhanelere dışarıdan kapı istendiği anlaşılmaktadır. Bu hücrelerden kuzeydoğuda olana bir zaman kapı açıldığ 1 , sonra kapatılıp ocak ve çinilerin ihya edildiği Ayverdi tarafından aktarılmaktadır (Ayverdi 1989, 50). Elimizdeki plandan anlaşıldığı kadarıyla 1552 yılı sonrası yapılan tadilatlardan birinde bu hücreler kapatılmıştır. 


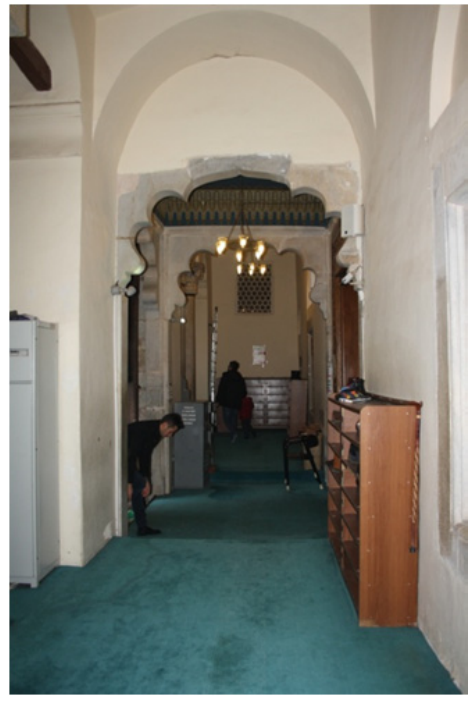

Fig. 17. Parvillée ve G. Fossatti Tarafindan Tasarlanan Pera'daki St. John Chisostom Roman Katolik Kilisesinin Açılışını Duyuran Gazete Haberindeki Görsel (1854), (M.A. Girardelli'den)

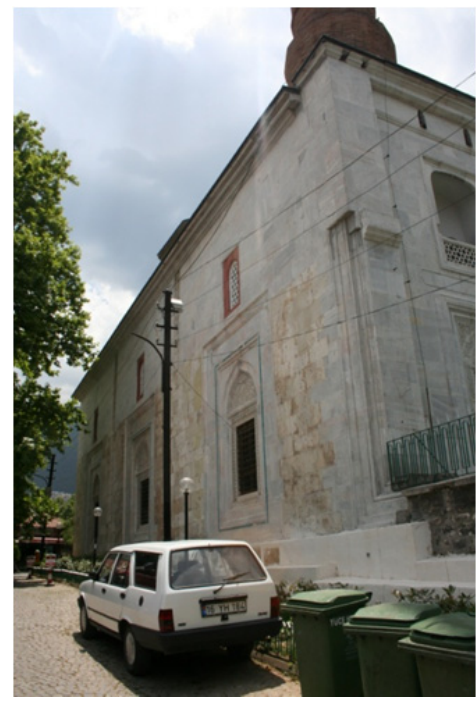

Fig. 18. Bursa Yeşil Cami Kuzey Cephesinde Tabhane Hücreleri ve Camiye Girişin Açıldığı Koridor ve Caminin Doğu Cephesi

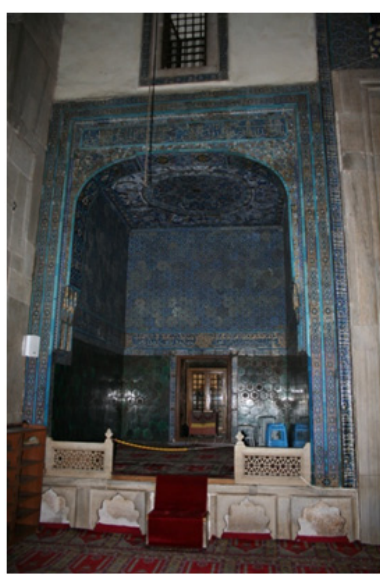

Fig. 19-20. Kuzey Cephedeki Alt Kat Locaları ve Pencereleri

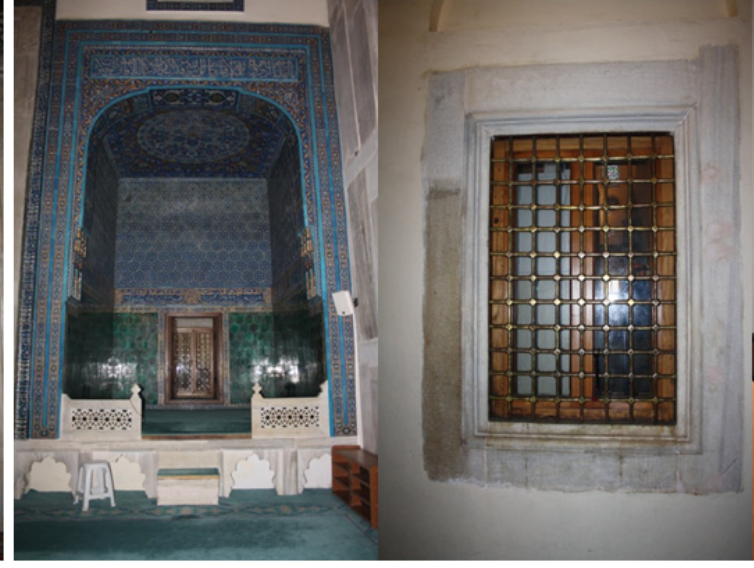

Fig. 21. Kuzeybatıdaki Loca Penceresinin Giriş Koridoruna Bakan Tarafi

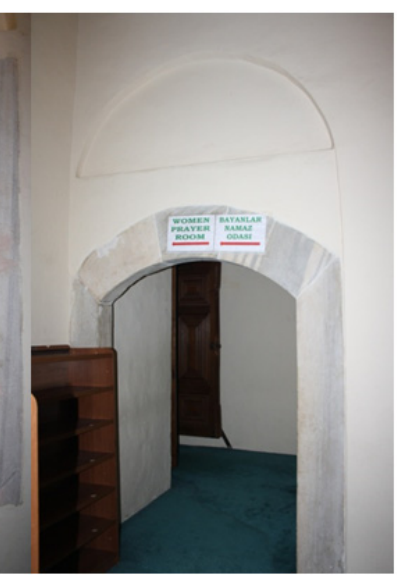

Fig. 22. Kuzeydoğu Tabhane Girişi

Ayverdi'den öğrenilen kuzeydoğudaki hücreye dışarıdan kapı açıldığ 1 bilgisi, tarihsiz planda görülen kuzeydoğuda yapının dışında var olan merdivenle desteklenmektedir (Fig. 2). Ancak bu cephede doğrudan dışarı açılan herhangi bir kapının izi seçilememektedir (Fig. 18). Planda bulunan tek açıklığın bu hücrenin penceresi olduğu anlaşılmaktadır. Yeşil Cami pencere parmaklıklarındaki kakma süslemelerle ilgili yapılan çalışmadan bu pencere parmaklıklarında süsleme bulunmadığı anlaşılmaktadır (Yalman 1991). 16. yüzyılın ikinci yarısından sonra kapatılmış bu tabhane hücrelerinden kuzeydoğuda bulunana girişin pencereden sağlanıp sağlanmadığı sorusunun cevabı muallâkta kalır. 1855 depremi sonrası yapılan tadilat sırasında da bu hücrelere yeniden yapının içinden giriş açıldığı arşiv planı ve Parvillée planının kıyaslanması ile anlaşılır. Arşivdeki planın verdiği diğer bir ilginç nokta caminin kuzey cephesindeki alt kat localarının kuzey cephelerinde bulunan pencerelerin bu planda görülmemesidir. Bu pencerelerin parmaklıkları da orijinal değildir. Tarihsiz plandan anlaşıldığı üzere, duvarlarından tavanına ve camiye bakan önyüzlerine kadar çini ve renkli nakışlarla kaplı bu locaların kuzey duvarlarına pencereler sonradan açılmıştır. Pencereleri kuşatan süsleme bordürünün pencerelerin üstünden 
geçen bordüre birleşimi de organik olmayıp, bir tadilatla değişikliğe işaret eder (Fig.19, 20).

$\mathrm{Bu}$ pencerelerin giriş koridoruna bakan yüzleri de kesme taştan lento ve sövelerle yapılmış olup, silme kuşakları ile çerçevelenmiştir (Fig. 21). Bu pencereler yapının tümünde görülen alt kat pencerelerinden malzeme, süsleme ve teknik açısından da farkl111k gösterir. Parvillée çiziminde bu pencereler mevcuttur. 1873 tarihli Usul-i Mimar-i Osmani'deki Yeşil Cami planında da alt kat localarının pencereleri görülmekte ve kuzey cephe tabhane girişleri günümüzdeki haliyle aynıdır. Kuzey cephedeki tabhane hücrelerinin girişlerinde yapılan değişiklikler sırasında bu hücrelerin önünde giriş alanı oluştu-

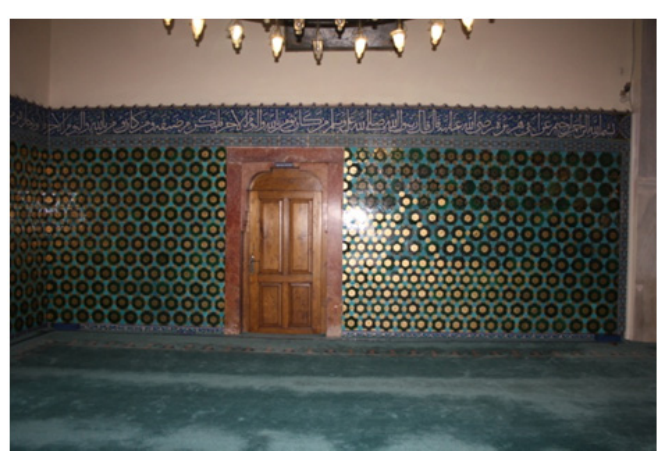

Fig. 23. Kuzeybatı Tabhane Hücresinden Batı Eyvanına Geçişi Sağlayan Kapı rulmuş ve giriş kapıları eklenmiştir (Fig. 22). Deprem sonrası hazırlanan planda görülmeyen ancak günümüzde camide bulunan detaylardan biri de kuzeybatı tabhane hücresine batı eyvanından açılmış kapıdır (Fig. 23, Fig. 2). Parvillée'ye ait planda (Fig. 3) olmadığ1 görülen kap1, 1873 tarihli Usul-i Mimar-i Osmani kitabında mevcuttur (Fig. 9). Bu kap1 1863-1873 y1llar1 arasındaki 10 yıllık süreçte eklenmiş olmalıdır ki arşivdeki 1867 tarihli belgeden restorasyonun bu tarihte halen tamamlanamadığı anlaşılmaktadır.

"Sultan Orhan ve Hüdavendigar Gazi Murad-ı evvel ve Yıldırım Bayezid
ve Çelebi Mehmed Sultan hazeratının cevami-i şerife ve türbe-i
münifelerinin vukubulan hareket-i arz tesiratıyla bazı mahelleri külliyen
münhedim olmuş, ve bazllarl dahi zedelenmiş olmaslyla bunların ekser
mahalleri saye-i ...hazret-i şehriyare inşa ve tamir kılınmış ise de henüz
reside-i derece-i ikmal olmamıs ve bu hal ile teşrifleri icra olunarak
kapalu kalmış olduğu Bursa'ya muvasalat kemteranemde nazar-ı
teessüfle görülmüş olduğu”" (BOA. MKT. MHM.386/87).

Başbakanlık Osmanlı Arşivi'ndeki planın verdiği ilginç noktalardan bir diğeri, planın çizildiği dönemde yapının ortasında şadırvanın bulunmamasıdır. Ayverdi, 1552 tarihli bir sicilden, caminin içinde şadırvan ve havuz olup, bu havuz ve şadırvandan dolayı namaz kılmak için kimsenin havuz etrafında saf tutmadığını, Cuma günleri kalabalık olup halkın sıkıntı çektiğini bu nedenle havuzun kaldırılması ve tabhanelerin yolunun da dışarı verilmesinin istendiğini, cami içinde ayende ve revendeye (gelene geçene yol olmayıp) temiz ve geniş olurdu denildiğini ve bu sözlerin makul bulunduğunun belgeden anlaşıldığını nakleder (Ayverdi 1989, 50). Evliya Çelebi, cami içinde bir şadırvan bulunup bulunmadığına değinmez (Kurşun, Kahraman 2011, 13). Texier'in de şadırvandan bahsetmediği görülür (Texier 2002, 225).

Toprak altında kalan havuzun Ahmed Vefik Paşa'nın valiliği sırasında tekrar açığa çıkarıldığını, daha önce kaybolmuş olan mermer fiskiyenin yine Ahmed Vefik Paşa döneminde bulunduğunu belirten araştırmacılar da vardır (Pay 2010, 44). Bu bilgi, şadırvanın 1552 yılı sonrası kaldırılmasının ardından 1863'e kadar henüz yeniden eklenmediğini düşündürtür. Usul-i Mimar-i Osmani kitabından, caminin ortasında şadırvan olduğu öğrenilmektedir (Edhem Paşa $2010,17)$ ve planda da şadırvan görülür. Parvillée çiziminde ise caminin ortasındaki şadırvan gösterilmemiştir (Fig. 3). Ancak, Parvillée'nin kitabında caminin içini gösteren resimde şadırvanın varlığı dikkati çeker (Fig. 24). Parvillée'nin, doğudaki minareden sonra bir detayı daha işlemediği anlaşılıyor. Bu resmin ne kadar realist olduğunu kestirememekle birlikte havuzun dışında baklava dilimi biçiminde süslemeler olduğu görülür. Şimdilerde Caminin ortasında bulunan havuz süslemesiz olup mermerdendir. 1880-1890'lı yıllarda çekilmiş fotoğrafta (Fig. 
25) havuzun şimdiki görünümüne benzediği dikkati çeker (Fig. 26).

Arşivde bulunan planda görülen detaylardan güneybatı tabhane hücresinin girişinin önündeki merdivenli yükselti muhtemelen bir mahfile işaret etmektedir. Parvillée çiziminde ve Usul-i Mimar-i Osmani kitabındaki planlarda bu detay bulunmaz. Parvillée'nin mihrap cephesini gösteren çiziminde de yine bu muhtemel mahfil detay1 yoktur (Fig. 3, Fig. 24) ve 1863 onarımı sırasında kaldırılmış olmalıdır. Zeminden yükseltilmiş güney cepheye çıkışın şimdi olduğu gibi cephenin ortasında bulunan basamaklarla sağlandığı da yine Parvillée çizimlerinden anlaşılmaktadır. Arşiv planında güneydoğu ve güneybatı tabhane hücrelerinin güney duvarları ortasında bulunan nişlerin çizilmediği fark edilir. Bunların yerinde bu nişlerin paralelinde bulunan üst kat pencereleri gösterilmiştir. Parvillée çiziminde de bu nişler işlenmemiştir. Ancak Usul-i Mimar-i Osmani kitabında bu nişler mevcuttur. Her iki nişin alınlığı da çini bezemeli olup aynı süsleme kompozisyonuna sahiptir. Cami içindeki (güney cephedeki pencerelerle eyvanlara açılan) pencerelerin tümü mermer alınlığa sa-

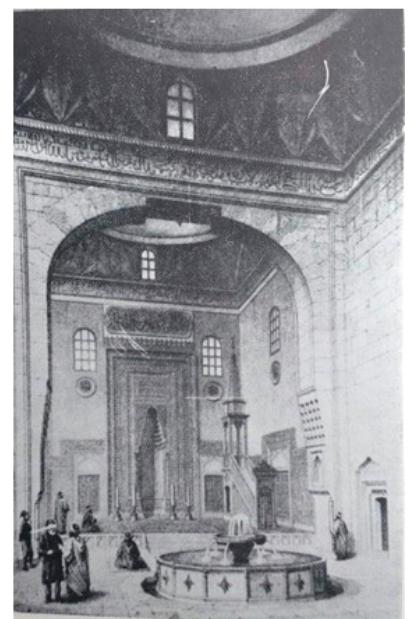

Fig. 24. Leon Parvillée'de Yapının Şadırvanı hiptir. Tabhane hücrelerindeki pencerelerin alınlıkları ise yine çiniden olup yazı kompozisyonları da içerir. Bahsi geçen nişler, eğer Parvillée yine bu detayları işlemeyi atlamamışsa, 18631873 yılları arasında Parvillée onarımı ya da sonrasında devam eden onarımda eklenmiş olmalıdır (Fig. 27-28). Arşiv belgesinde görülen caminin dışında kuzey cephede bulunan dört basamaklı merdivenle çıkılan alan ne Parvillée'de nede Usul-i Mimar-i Osmani kitabında vardır. Ancak bu alanın 1852 yılında yapının önünde mevcut olduğu sanatçısı bilinmeyen 1852 tarihli bir gravürde görülür (Fig. 12). Taç kapının doğusundaki ilk pencerenin önünde bulunan bu merdivenli yükseltinin pencere önüne eklenen bir sundurma ile tamamlandığı anlaşılıyor. Muhtemelen gölgelikli bir oturma alanı olarak tasarlanmış bu alan, deprem sonrası hazırlanan planda ve bu gravürde olduğu gibi taç kapının doğusundaki ilk pencere önündedir. Bu merdivenle birlikte doğu cephede bulunan merdiven de 1863 onarımındaki cephe düzenlemeleri sırasında kaldırılmış olmalıdır.

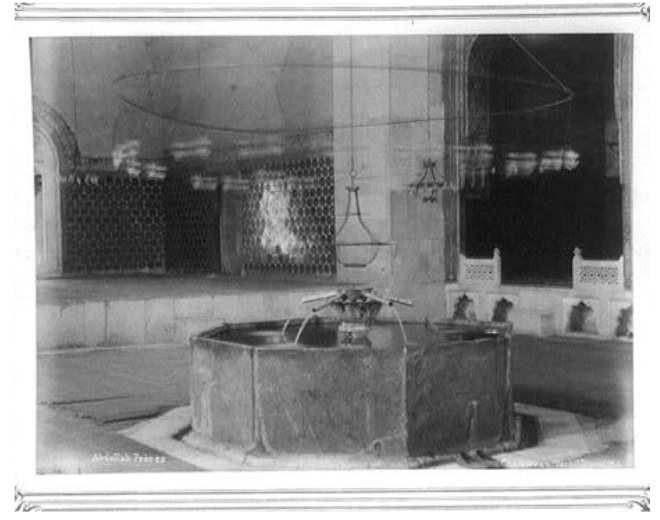

Fig. 25. 1880-1890'lı Yıllarda Yeşil Cami Şadırvanı https://www.loc.gov/item/ 2003668039/

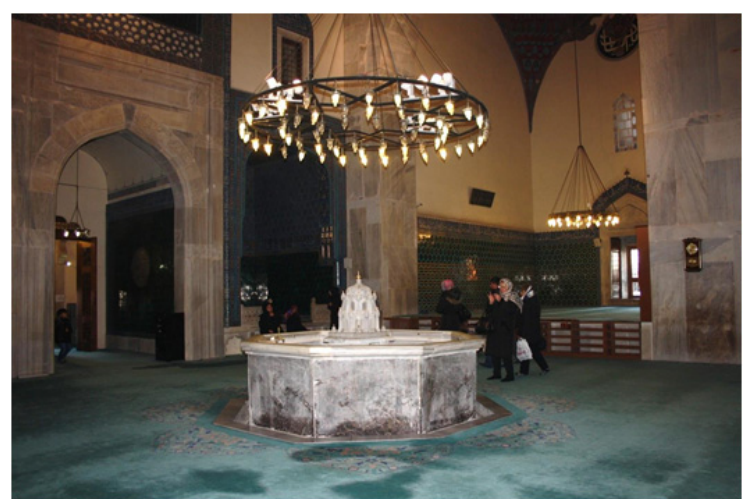

Fig. 26. Bursa Yeşil Cami Şadırvanı

Yeşil Türbe'nin planında 1855 sonrası yapılmış olabilecek değişikliklere geçtiğimizde, 1855 depremi sonrası türbe az hasarlı olarak rapor edilmiştir (Oğuzoğlu 2001, 82). Türbenin günümüzdeki planı ile arşivdeki planı arasında farklılıklar bulunur. Bu farklılıklar türbe binasından ziyade türbe içinde ve çevresindedir. Arşiv planında yedi adet sanduka görülürken (Fig. 2) 
günümüzde türbede dokuz adet sanduka vardır. Türbe içinde tespit edilebilen tek fark Çelebi Mehmed'in sandukasının güneyindeki iki kabrin işlenmemiş olmasıdır. Yeşil Türbeyi ziyaret eden seyyahların anlatılarında da sanduka sayısının 5'le 9 arasında değiştiği görülür (Yıldırım 2014, 460). Çelebi Mehmed'in sandukasının iki yanındaki sandukalar çocuk şehzadelere aittir. Güneyde iki ve kuzeyde bir olmak üzere toplamda üç adet çocuk şehzade sandukası vardır ve bu üç sandukada aynı malzeme ile yapılmıştır.

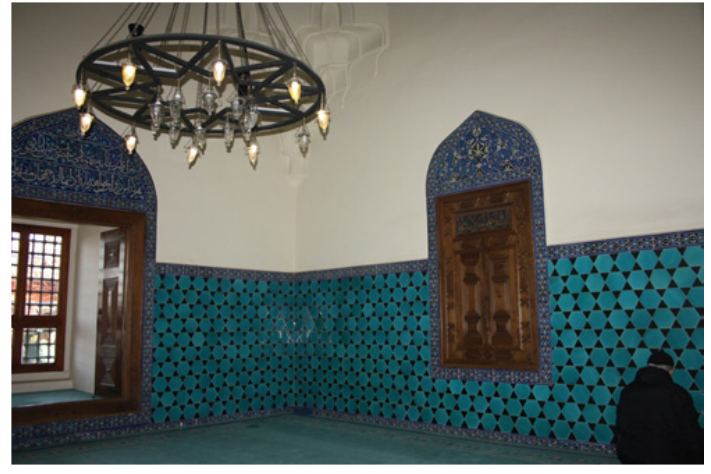

Fig. 27. Güneydoğu Tabhane Hücresindeki Niş

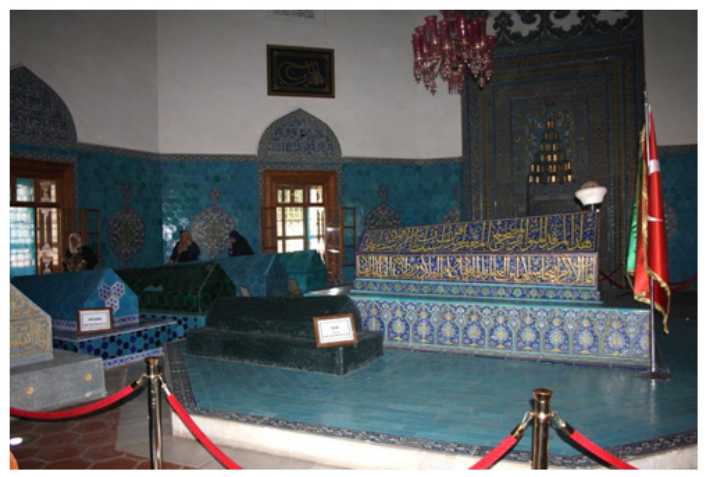

Fig. 29. Çelebi Mehmed Türbesi İçi

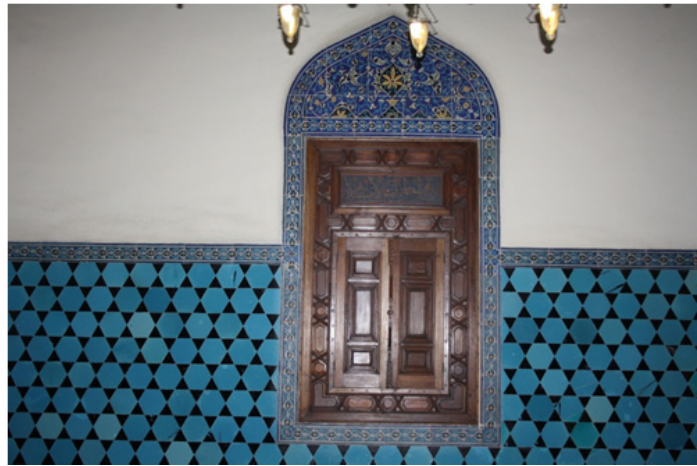

Fig. 28. Güneybatı Tabhane Hücresindeki Niş

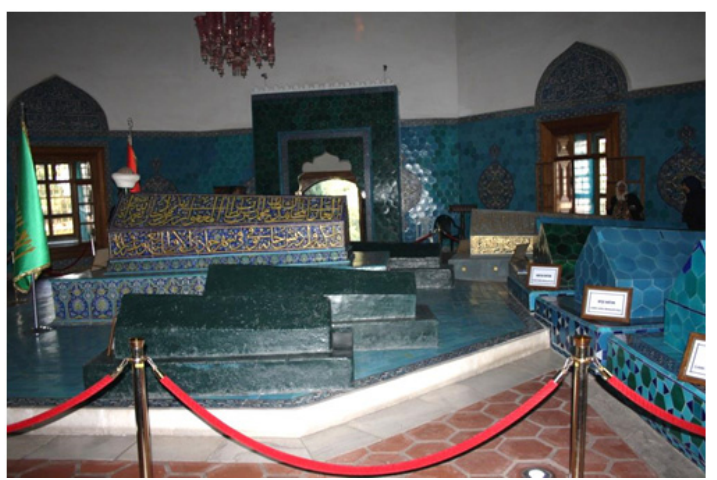

Fig. 30. Çelebi Mehmed'in Sandukasının

Güneyinde Bulunan ve Muhtemelen 1863 Sonras1 Eklenmiş Şehzade Sandukaları

Kuzeyde bulunan ve arşiv belgesinde de çizilen sanduka Çelebi Mehmed'in kabrinin sekizgen kaidesinin süsleme bordürleri içinde kalır (Fig. 29).Güneyde bulunan ve muhtemelen 1863 onarımları sırasında eklenen iki şehzade sandukasından mihraba yakın olan sanduka, bu sekizgen kaidenin çevre bordürünün üzerindedir (Fig. 30). Çocuk şehzade kabirlerinde aynı malzemenin kullanılması kuzeyde bulunan sandukanın da güneydekilerle aynı anda tamir edilerek yenilenmiş olabileceğini düşündürür. Bu mezarların 1863 onarımlarında türbeye eklendiğini hem arşivdeki plan hem de 1863 tarihli belge ortaya koyar. Başbakanlık Osmanlı Arşivi'nde bulunan evkaf defterinde:

"Çelebi Sultan türbe-i müzeyyeneleri çinileriyle yol mühendisine ve Bursada olan inşaatına ve seylden harab olan mahaller tamiratına ve kabristan ve Çelebi Sultan Efendimiz havlilerinin parmakliklarina ve cami-i şeriflerinin ......tarafi tesviyesine ....kaffe-i müş̧temilatıyla beraber yapılmasina ve hatta .... mahsus kabristanin bile tamirine" (BOA. EV.D. 21185).

ifadeleri 1863 tadilatının kabristana kadar genişletildiğini gösterir. Arşiv planında türbenin dışında dört adet sanduka tespit edilebilmektedir. Günümüzde burada bulunan sanduka sayısı ise 
üçtür. Yeşil Türbe merdivenlerinin batısında küçük bir kabristan daha vardır ve bahsi geçen planda bu kabristan detaylandırılmadan kabristan olarak yeri belirtilmiştir (Fig. 2). Tüm bu değişiklikler kabristanın tamiri ifadesi altında toplanmış olur. Parvillée'nin çizdiği Yeşil Türbe planı ise sandukaların işlenmemesi nedeniyle bu durumu aydınlatmada yardımcı olmaz.

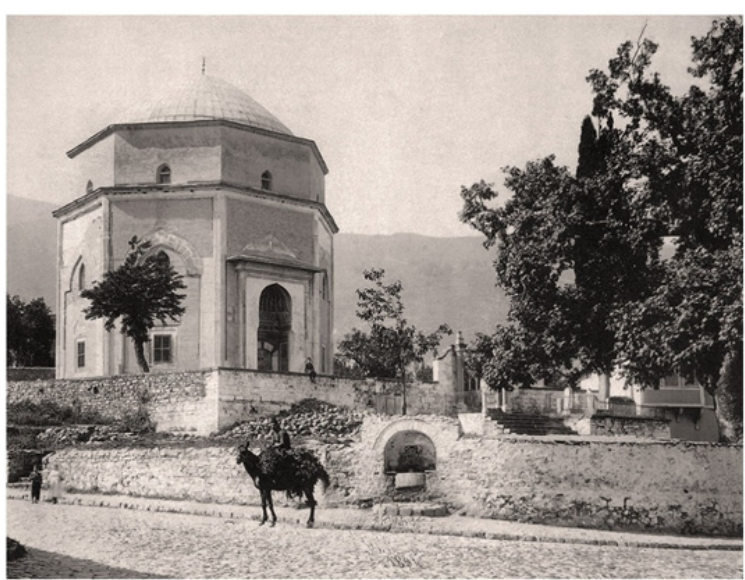

Fig. 31. 1894 yılında Bursa Yeşil Türbe ve Civarı (http://www.dergibursa.com.tr/eski-bursanin-nostaljikizleri/)

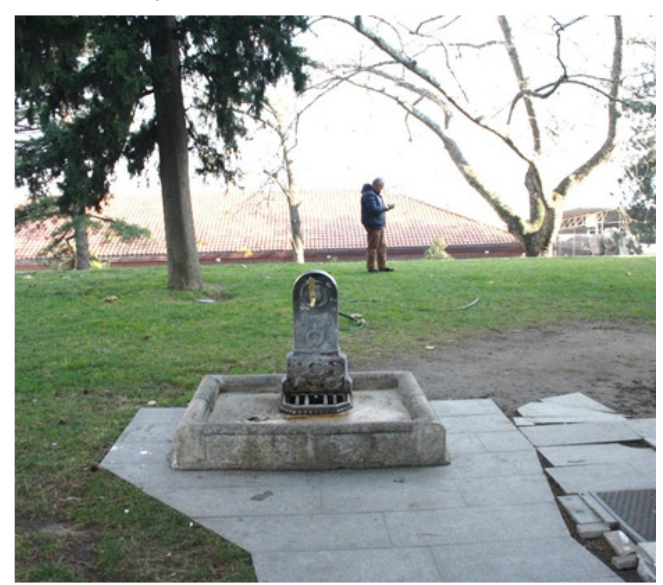

Fig. 32. Yeşil Türbe Yakınında Bulunan Çeşme

Arşiv planında ise cami ve türbe yakınında üç çeşme iki de şadırvan işlenmiştir. Cami ve türbe civarında günümüzde tek bir çeşme vardır. Başbakanlık Osmanlı Arşivi'nde bulunan 1621 tarihli belgeden "medrese, cami-i şerif ve vesair çeşmelerin tamirine" BOA. EV.D. 24181) tanımlamasından külliyede birden fazla çeșmenin olduğu kesinleșir. Muradiye Külliyesi avlusundan bulunan taş eserler arasında 1801 tarihli Çelebi Mehmed Camisi Kapıcısı Ali Efendi Çeşmesi'nin kırık kitabe parçaları vardır. Planda görülen çeşmelerden ikisi türbeyi çevreleyen duvardadır. Merdivenin iki yanındaki çeşmelerden güneydoğuda olanın 1894 yılına kadar varlığını koruduğu eski Bursa fotoğraflarından anlaşılmaktadır (Fig. 31). Aynı fotoğrafın açısına girmesi gereken ve türbeyi çevreleyen ikinci kademe duvarına bitişik olan türbedar odası, çeşme ve başka bir mekânın fotoğrafının çekildiği tarihe kadar kaldırılmış olduğu anlaşılıyor.

Türbenin önünde ve yine türbenin doğusundaki sandukaların yanındaki şadırvanlarında 1894 tarihli fotoğrafın kadrajına girmediği farkedilir. $\mathrm{Bu}$ şadırvanlardan türbenin önünde bulunanın yerinde şimdilerde küçük bir çeşme vardır. Tarihsiz çeşme üzerinde bulunan süslemeler geç dönem özellikleri göstermektedir (Fig. 32). Planda, kare formlu olarak tasvir edilmiş şadırvanda olduğu gibi bu çeşmede kare bir zemin üzerindedir. Külliyede yapılan onarımlarda şadırvanın kaldırılmasının ardından bu çeşme eklenmiştir. Günümüzde cami yakında tarihi tuvalet bulunmaz. 1645 tarihli bir belgeden caminin yakınında 6 adet tuvalet bulunduğu öğrenilmektedir (Ayverdi 1989, 51). Bu belge ile Başbakanlık Osmanlı Arşivi'nde bulunan plan bu açıdan uyuşmaktadır. Planda görülen altı tuvalet bilinmeyen bir tarihte kaldırılmıştır.

\section{Değerlendirme ve Sonuç}

Bursa için önemli tarihlerden olan 1855 y1lında yaşanan büyük depremle birlikte, bu kentte tamir ve imar çalışmaları başlamıştır. Özellikle Tanzimat döneminin önde gelen isimlerinden Ahmed Vefik Paşa'nın girişimleri ve çabasıyla, Bursa'da 1863-1882 yılları arasında Batı tarzı şehircilik ve inşaat yöntemleriyle Osmanlı zanaatı, mimari anlayışı ve geleneksel kent dokusu arasında bir birliktelik kurulabilmiştir (Saint Laurent 1996, 83). Ahmed Vefik Paşa'nın yönetimi sırasında yoğunlaşan ve mimar olarak seçilen Leon Parvillée'nin gerçekleştirdiği tamirat çalışmalarına dair yeterince bilgi bulunmaz. Bilinenler: Ulu Cami'nin “yeniden” inşa edilmiş olması 
ve bununda Parvillée'nin hocası Violet-le-Duc'un restorasyon yaklaşımını benimsediğini gösterdiği şeklinde yorumlanmasıdır (Tosun 2008, 91). Diğer bilinenler, Yeşil Cami'nin kubbesinin onarımı, Yeşil Cami ve Türbe'sinin çinilerinin ve türbe vitraylarının onarımı, Orhan Zaviyesi ile Muradiye Külliyesi avlusunda bulunan türbelerin onarımıdır. Bu restorasyonlara öncülük ettiği bilinen Ahmed Vefik Paşa ile Leon Parvillée dışında, onarım ekibinden üçüncü bir isim de zikredilmez.

Bursa Yeşil Camisini içine dahil ederek yazılmış en eski mimari kitaplardan olan Usul-i Mimar-i Osmani kitabında, caminin kubbesi üzerindeki "fener tabir olunan mahallin" tamir edildiği söylenir (Oğuzoğlu 2001, 82). Bu kitapta ayrıca 1855 depremi sonrası Ahmed Vefik Paşa'nın kontrolünde gerçekleştirilen onarımlarda türbenin vitraylarının Ahmed Vefik Paşa tarafından titizlikle tamir edildiği, caminin yıkılan büyük kubbesinin ise 1500 Osmanlı altını harcanarak tamir edileceğinin hesaplandığ 1 fakat söz konusu kubbeye demirden yapılmış çemberler geçirildikten sonra çatlak olan yerlere sıvı çimento akıtıldı̆̆ 1 ve bu şekilde tamir edilen kubbenin masrafının hesaplanandan daha az bir paraya yapıldığı açıklanır (Edhem Paşa 2010, 19). Daha ilginç olan ifadeyse, bu tamir konusunda geniş açıklamalar yapılmasının işin önemini hafifleteceğinden, yalnız bu kadarının belirtilmekle yetinildiğinin ifade edilmesidir (Edhem Paşa 2010, 19). Osmanlının uluslararası sergilerde kendini temsili üzerine hazırlanmış bu çalışmada, tamiratın yapının kıymetini ve Osmanlı yöneticilerince kendi mimarilerinin önemli yapılarından biri olarak seçilmiş Yeşil Cami'nin önemini azaltacağına dair olan bu endişe ve çekince, Parvillée'nin bu camide yaptığı onarım uygulamalarının es geçilmesine de neden olmuştur.

Bir anıtı restore değil de tamir ederken orijinaline sadık kalma düşüncesinin fikir olarak 19. yüzyılın ikinci yarısında var olmadığ 1 ve çok yeni bir fikir olduğu kabul edilmektedir (Aoki 2002, 139). Bu fikir Osmanlı mimarlığında "Tarz-ı kadîm Üzere Tamir" olarak bilinmektedir ve 18. yüzyılda uygulandığına dair arşiv bigileri bulunmaktadır (Dündar 2001, 275:276). Eski eserlerin değerini kavrayarak çağdaş tasarımla canlandırmak, 19. yüzyıl Fransa'sında Parvillée'nin hocası Viollet-le-Duc'un iddia ettiği bir yöntemdir (Aoki 2002, 140). Parvillée, Fransa'daki yaygin restorasyon ilkelerini benimsemiştir ve buradan ayrılmadan önce Viollet-le-Duc'la ve onun restorasyonda ve mimari teorisindeki yeni bilimsel yaklaşımıyla iletişim halinde olmalıdır (Saint Laurent 1986, 258). Ahmed Vefik Paşa'nın, Yeşil Cami'nin 1863 onarımında oynadığı rol net olarak bilinemese de, bu onarımda önemli pay sahibi olduğu kesindir. Onun döneminde inşa edilmiş Bursa Hükümet Konağı'nın, bina dışındaki neoklasik üslupta süslemelere karşılık, iç yerleşimin geleneksel Osmanlı konağı planında olması (Saint Laurent 1996, 91) aslında Ahmed Vefik Paşa'nın geleneksel olanla yeni olanın birleştirilmesindeki “açık fikirliliğini”"de gösterir. Aynı açık fikirlilik, geleneksel dini mimariye yeni dokunuşlarda bir beis görülmemesinin de temelinde yatmaktadır. Yeşil Cami'de görülen Parvillée dokunuşlarından devşirme Doğu Roma sütunları, yapının kapısı önüne eklenen ampir üsluptaki sundurma buna örnektir. Ahmed Vefik Paşa bu unsurları kendisi eklememiş olsa bile en azından onarımın baş yöneticisi olarak, onarım için çağırdığı mimarla uyuşmuş olmalı ki bu detaylar yapıya eklenebilsin.

Osmanlıda tamir işlerinin başlayabilmesi için ilk olarak eserin onarıma muhtaç olduğunun Divân-1 Hümâyûn'a bildirilmesi gerekmekteydi (Dündar 2001, 272). Ardından yapılan işlemler, bir ön araştırmanın ardından Mimar Ağa'ya keşif için yazı havale edilmesi, Mimar Ağa'nın uygun gördüğü Hassa mimarının saraya bildirilmesiydi. Mimar, Divân-1 Hümâyûn tarafından görevlendirilmesinin ardından, keşif yapıp restorasyon çizimlerini ve keşif defterlerini hazırlamaktaydı (Dündar 2001, 272). Başbakanlık Osmanlı Arşivi'nde bu şekilde hazırlanmış çizimler bulunmaktadır (Dündar 2000). Bursa Yeşil Cami ve Türbesi'ne ait bu çizimlerin duyulan ihtiyaç üzerine yapının deprem sonrası mevcut durumunu gösterir şekilde hazırlandığı planın yanında bulunan ifadelerden anlaşılmaktadır. 
$\mathrm{Bu}$ çalışmanın temel çıkış noktasını oluşturan Başbakanlık Osmanlı Arşivi'nde bulunan plan üzerinden değerlendirilmeler yapılmıştır. Tarihsiz olmasına karşılık bir deprem sonrası hazırlanmış planın (üzerinde görülen ve görülmeyen detaylarla) tarihi görseller, bilgi ve belgelerle kıyaslandığında, 1855 depremi sonrası Bursa Yeşil Cami ve Türbe'nin mevcut durumunu gösteren planlar olduğu tespit edilmiştir. 1863 de Parvillée tarafından yapılan çizimle ve 1873 tarihli Usul-i Mimar-i Osmani kitabındaki çizimlerle kıyaslanarak yapılan çıkarımlar sonrası Leon Parvillée ve Ahmed Vefik Paşa işbirliğinde yapılan onarımlarda: yapının doğusuna eklenen minare ile çifte minareli hale getirildiği, bu minarelerin simetrik olduğu anlaşılmıştır. Bu tarihte yapılan diğer değişikliklerin, yapının önünde kuzeydoğu pencere önünde bulunan sundurmanın kaldırılması, kapı üzerindeki sundurmanın değiștirilmesi ve ampir üslupta bir sundurma eklenmesi şeklinde tespit edilmiştir. Yapının içinde kuzey cephesinde devşirme sütunların eklenerek bir son cemaat yeri oluşturulma girişimi de tespit edilen diğer önemli husustur. Kuzeydoğu ve kuzeybatı tabhane girişlerinde yapılan değişiklikler, alt kat localarının ortasına birer pencere açılması ki bu sayede içerde oluşturulan son cemaat yeri ile ses ve 1şık akışı sağlanmış olmalıdır ve yine bu pencerelerde içerde oluşturulan son cemaat bölümünü tamamlamaya yöneliktir. Caminin ortasına şadırvan eklenmiş, güneybatı tabhane hücresi önünde bulunan muhtemel mahfil kaldırılmıştır. Parvillée onarımında gerçekleştirildiği kesin olmayan ancak 1873 yılına kadar yapılmış diğer bir değişiklik güneybatı ve güneydoğu tabhane hücrelerinin güney duvarlarına niş açılmasıdır. Parvillée onarımına ait olmayan ancak 1873 yılına kadar yapılan değişikliklerden birisi de kuzeybatı tabhane hücresinden batı eyvanına kapı açılmasıdır.

1855 depreminden sonra çizilmiş bu planda görülen değişikliklerden bazılarının tarihleri ise tespit edilememiştir. Bunlar: caminin dışında doğu duvarında bulunan merdivenin kaldırılması, caminin doğusundaki altı adet tuvaletin kaldırılması, türbe çevresindeki çeşmelerden ikisinin kaldırılması, iki şadırvandan birinin kaldırılması diğerinin yerine çeşme inşa edilmesi, türbenin dışındaki dört sandukadan birinin kaldırılmasıdır. 


\section{KAYNAKÇA}

Akün Ö. F. (1989). “Ahmed Vefik Paşa”. Türkiye Diyanet Vakfi İslam Ansiklopedisi (Cilt 2) 143-157. İstanbul 1989.

Aoki M. (2002). Léon Parvillée: Osmanlı Modernleşmesinin Eşiğinde Bir Fransız Sanatçı. Yayımlanmamış Doktora Tezi. İstanbul Teknik Üniversitesi, İstanbul 2002.

Ayverdi E. H. (1989). Osmanlı Mimarisinde Çelebi ve II. Sultan Murad Devri II. İstanbul 1989.

Dündar A. (2000). Arşivlerdeki Plân ve Çizimler Işığl Altında Osmanlı İmar Sistemi (XVIII. ve XIX. Yüzyll). Ankara 2000.

Dündar A. (2001). "Osmanlılarda Tamir Süreci, Çeşitleri ve Bazı Selçuklu Yapılarındaki Uygulamalar". I. Uluslararast Selçuklu Kültür ve Medeniyeti Kongresi Bildiriler I (Konya 2000) (2001) 269-280.

Edhem Paşa. (2010). Osmanlı Mimarisi, Usûl-i Mi'mârîi Osmânî. Der. İ. Ovalığlu - R. Gündoğdu. İstanbul 2010.

Ermiş M. (2016). "The Reuse of Byzantine Spolia in the Green Mosque of Bursa". Art-Sanat 6 (2016) 99108.

Eroğlu S. \& Güleç H.B. (2016). "Victoria and Albert Müzesi Deposunda Bulunan Yeşil Cami ve Yeşil Türbe'nin Çinileri ile Leon Parvillée İlişkisi”. Uluslararası Sosyal Araştırmalar Dergisi 9/47 (2016) 331-352.

Gabriel A. (2010). Bir Türk Başkenti Bursa. Cilt I (Yeniden Basım). İstanbul 2010.

Girardelli M. A. (2013). "Leon Parvillée Early Years in Istanbul: Cezayirlioğlu Mansion and the Church of Surp Krikor Lusavoriç in Kuzguncuk". $14^{\text {th }}$ International Congress of Turkish Art (Paris 2013). (2013) 67-73.

Hızlı M. (1993). "Hüdâvendigâr Vilâyeti İmar Faaliyetleri Defteri (1307-1309/1891-1893)". Uludă̆ Üniversitesi İlahiyat Fakültesi Dergisi 5/5 (1993) 233-254.

Kurlı C. (2008). Sultan ve Kaтиоуи. İstanbul 2008.

Kuban D. (2007). Osmanlı Mimarisi. İstanbul 2007.

Kurşun Z. \& Kahraman S. A. (2011). Evliya Çelebi Seyahatnamesi 1-6. Kitaplar, 2. Kitap. İstanbul 2011.

Oğuzoğlu Y. (2001). "Osmanlı Arșivi Kayıtlarına Göre 1855 Bursa Depremi”. Ed. Nurcan Abacı, Bursa Yöresi'nin Depremselliği ve Deprem Tarihi (2001) 81-88. Bursa.

Özbek Y. (2002). Osmanlı Beyliği Mimarisinde Taş Süsleme. Ankara 2002.

Özcan B. (1999). "Bursa Depremleri (2 Mart, 12 Nisan 1855)". Atatürk Üniversitesi Güzel Sanatlar Enstitüsü Dergisi 5 (1999) 73-118.

Pay S. (2010). Kuruluşundan Günümüze Yeşil Külliyesi. Bursa 2010.

Saint-Laurent B. (1986). "Leon Parvillée, His Role as Restorer of Bursa's Monuments and His Contribution to the Exposition Universelle of 1867". Ed. H. Batu \& J. L. Grammont, L'empire Ottoman, la République de Turquie et la France (1986) 247-282. İstanbul.

Saint-Laurent B. (1996). "Bir Tiyatro Amatörü: Ahmet Vefik Paşa ve 19. Yüzyılın Son Çeyreğinde Bursa'nın Yeniden Biçimlenmesi”. Ed. P. Dumont \& F. Goergeon, Modernleşme Sürecinde Osmanll Kentleri (1996) 79-99. İstanbul.

Sevim M. (1997). Gravürlerle Türkiye, Anadolu I. Ankara 1997.

Tansel F. A. (1964). "Ahmed Vefik Paşa". Belleten 109 (1964) 117-139.

Tekinalp M. (2010). "Remodelling The Monastery of Hagios Ioannes in Prusa ad Olympum (Modern Bursa, Turkey)". Trudy Gosudarstvennogo Ermitaja-the State Hermitage Papers 53 (2010) 162-177.

Texier C. (2002). Küçük Asya, Coğrafyası, Tarihi ve Arkeolojisi I. Ankara 2002.

Tosun Ç. B. (2008). Eugéne Emmanuel Viollet-le Duc (1814-1879) ve Etkileri. Yayımlanmamış Doktora Tezi. Hacettepe Üniversitesi, Ankara 2008.

Yalman B. (1991). Bursa Yeşil Cami Pencere Parmaklıklarındaki Gümüs Kakma Motifler. Yayımlanmamış Doktora Tezi. İstanbul Üniversitesi, İstanbul 1991.

Yavaş D. (2009). "Bursa Yeşil Camide Yapılan Onarımlar". Türk Dünyası Araştırmaları Dergisi. Prof. Dr. Oktay Aslanapa Özel Saylst (2009) 589-598. 
Yıldırım F. (2014). 14. Yüzylldan Cumhuriyet Dönemi'ne Kadar Yabancı Seyyahların Gözünden Bursa İlindeki Mimari Eserler. Bursa 2014.

\section{Başbakanlık Osmanlı Arşivi Vesikaları (BOA)}

BOA. (A.MKT.NZD.) Dosya No: 144, Gömlek No: 56.

BOA. (A.AMD.) Dosya No: 54, Gömlek No: 79.

BOA. (A.MKT.MHM.) Dosya No:233, Gömlek No:52.

BOA. (A.MKT.MVL.) Dosya No:71 Gömlek No: 70.

BOA.( A.MKT.MVL.) Dosya No:75 Gömlek No: 59.

BOA. (A.MKT.MVL.) Dosya No:76 Gömlek No: 73.

BOA. (A.MKT.MHM.) Dosya No:363, Gömlek No:22.

BOA. Evkaf Defteri, (EV.D) No: 24181.

BOA. Evkaf Defteri, (EV.D)Dosya No: 15785.

BOA. Evkaf Defteri, (EV.D)Defter No: 21185.

BOA. Evkaf Defteri (EV.D)Defter No: 24181.

BOA. Evkaf Defteri, (EV.D)No:15785.

BOA. (MKT. MHM.) Dosya No:386/87, Gömlek No: 3.

BOA. Plan Proje Kroki, (PLK.) Dosya No: 03443.

\section{Elektronik Kaynaklar}

lint.com/_phv_app.php?/p/1_Sebah_Joaillier Erişim tarihi 26.03.2017

$\mathrm{http}: / /$ bibliothequenumerique.inha.fr/collection/?esq $=$ bursa\&esa $=$ resetall\&navigation $=0 \& \mathrm{x}=0 \& \mathrm{y}=0$

Erişim Tarihi 04.04.2017

https://www.loc.gov/item/2003668039/26.03.2017

http://www.dergibursa.com.tr/eski-bursanin-nostaljik-izleri/ 
